\title{
Climate implications on forest above- and belowground carbon allocation patterns along a tropical elevation gradient on $\mathrm{Mt}$. Kilimanjaro (Tanzania)
}

\author{
Natalia Sierra Cornejo ${ }^{1}$ (D) Christoph Leuschner ${ }^{1}$. Joscha N. Becker ${ }^{2} \cdot$ Andreas Hemp $^{3}$. \\ David Schellenberger Costa ${ }^{4}$. Dietrich Hertel ${ }^{1}$
}

Received: 23 July 2020 / Accepted: 14 January 2021 / Published online: 25 February 2021

(c) The Author(s) 2021

\begin{abstract}
Tropical forests represent the largest store of terrestrial biomass carbon (C) on earth and contribute over-proportionally to global terrestrial net primary productivity (NPP). How climate change is affecting NPP and C allocation to tree components in forests is not well understood. This is true for tropical forests, but particularly for African tropical forests. Studying forest ecosystems along elevation and related temperature and moisture gradients is one possible approach to address this question. However, the inclusion of belowground productivity data in such studies is scarce. On Mt. Kilimanjaro (Tanzania), we studied aboveground (wood increment, litter fall) and belowground (fine and coarse root) NPP along three elevation transects (c. 1800-3900 $\mathrm{m}$ a.s.l.) across four tropical montane forest types to derive $\mathrm{C}$ allocation to the major tree components. Total NPP declined continuously with elevation from 8.5 to $2.8 \mathrm{Mg} \mathrm{C} \mathrm{ha}^{-1} \mathrm{year}^{-1}$ due to significant decline in aboveground NPP, while fine root productivity (sequential coring approach) remained unvaried with around $2 \mathrm{Mg} \mathrm{Cha}^{-1}$ year $^{-1}$, indicating a marked shift in $\mathrm{C}$ allocation to belowground components with elevation. The $\mathrm{C}$ and $\mathrm{N}$ fluxes to the soil via root litter were far more important than leaf litter inputs in the subalpine Erica forest. Thus, the shift of $\mathrm{C}$ allocation to belowground organs with elevation at Mt. Kilimanjaro and other tropical forests suggests increasing nitrogen limitation of aboveground tree growth at higher elevations. Our results show that studying fine root productivity is crucial to understand climate effects on the carbon cycle in tropical forests.
\end{abstract}

Keywords Africa $\cdot$ Carbon cycle $\cdot$ Fine roots $\cdot$ Net primary production $\cdot$ Tropical montane forest

Communicated by Rodrigo Vargas.

Natalia Sierra Cornejo

nsierra@gwdg.de

1 Department of Plant Ecology and Ecosystems Research, Albrecht Von Haller Institute for Plant Sciences, Georg August University of Goettingen, Göttingen, Germany

2 Institute of Soil Science, Center for Earth System Research and Sustainability (CEN), University of Hamburg, Hamburg, Germany

3 Department of Plant Physiology, Bayreuth University, Bayreuth, Germany

4 Institute for Ecology and Evolution, Friedrich Schiller University of Jena, Jena, Germany

\section{Introduction}

Tropical forests cover only $13 \%$ of the earth's land surface but may account for one-third of terrestrial net primary productivity (NPP) (Del Grosso 2008) and store 40-50\% of the terrestrial biomass carbon (Houghton 2005; Lewis et al. 2009). Climate change has the potential to reduce the forests' sink strength for carbon (C) in a hotter and drier climate through reduced $\mathrm{CO}_{2}$ uptake, increased respiratory $\mathrm{CO}_{2}$ release, or both (Lloyd and Farquhar 2008; Cernusak et al. 2013; Mitchard 2018). Changing temperature and moisture conditions may also affect the patterns of carbohydrate allocation to aboveground and belowground sinks, i.e. wood increment, the production of leaves, flowers and fruits, root production, root exudation, and $\mathrm{C}$ transfer to mycorrhiza. For example, warmer temperatures tend to accelerate soil nitrogen $(\mathrm{N})$ cycling with the consequence of better nutrient supply and higher aboveground productivity at the 
cost of root productivity (Robertson and Groffman 2015; Moser et al. 2011). Yet, higher temperatures also increase the atmospheric vapor pressure deficit, which can induce drought stress with negative effects on forest productivity even in situations when soil moisture is not limiting (Yuan et al. 2019). On the other hand, climate warming could also lead to increased precipitation, as is predicted by climate change scenarios for parts of East Africa (Niang et al. 2014), possibly hampering root growth in already wet soils. Thus, wood production and timber yield may decrease or increase with climate change as a consequence of allocation shifts, independently of changes in total forest productivity. How long-term change toward a hotter climate with higher evaporative demand influences the $\mathrm{C}$ cycle of tropical forests is hence only poorly understood, further studies being needed (Wood et al. 2012). One reason for this lack of understanding is that most productivity studies in tropical forests have considered only aboveground components of productivity (wood and leaf production) while ignoring belowground productivity. Measuring root productivity is labor-intensive, especially with respect to the fine root fraction (conventionally roots $<2 \mathrm{~mm}$ in diameter). The synchronization of root growth and root mortality, together with the high spatial heterogeneity of the root system makes the observation of root dynamics notoriously difficult (Eissenstat et al. 2000). Consequently, various authors have used estimates of root production to obtain total (above- and belowground) productivity, but these production figures should be considered with caution.

A second reason for this limited understanding is the existence of contradicting evidence with respect to the temperature dependence of net primary productivity (NPP) of tropical and subtropical forests, i.e. the balance of photosynthetic carbon gain and carbon loss through autotrophic respiration. The climatic control of forest NPP is still a matter of debate, as several studies provide evidence for a direct temperature dependence of productivity (Huxman et al. 2004; Leuschner et al. 2013; Lichstein et al. 2014; Chu et al. 2015), while other investigations point to a more prominent role of solar radiation, tree functional traits and stand structural attributes as principal drivers of forest NPP (Luyssaert et al. 2007; Michaletz et al. 2014; Fyllas et al. 2017).

Some insights on the importance of climatic drivers can be gained from the comparative study of forest productivity along climate or elevation gradients. Even though these gradients are often linked with a change in other environmental factors, they have the advantage of informing longterm acclimative and adaptive responses of trees to climate warming. We are aware of only two comprehensive studies along tropical elevation gradients that covered the major above- and belowground components of forest productivity, i.e. the study by Girardin et al. (2010) and Malhi et al. (2017) in the Peruvian Andes, and the study by Moser et al.
(2011) and Leuschner et al. (2013) in the Ecuadorian Andes. Since root production was also investigated, these two pioneer studies allow conclusions on carbon allocation shifts along the elevation gradient that may relate to alterations in temperature, moisture and nutrient availability. Both studies found increased carbon allocation to root production with increasing elevation, but the extent to which the shift occurred, differed. Moreover, both studies report deviating elevational trends for total NPP, carbon partitioning and fine root carbon residence time, highlighting the regional character of the observed patterns. This suggests that local differences in climate and geology, and probably also in the biogeographical setting, may lead to deviating patterns of NPP and carbon allocation change with elevation in different tropical mountains (Malhi et al. 2011). Comprehensive studies of forest NPP and its components along elevational gradients are lacking in the African and Asian tropical forest realms so far.

Measuring aboveground and belowground productivity in combination with the corresponding biomass $\mathrm{C}$ pools allows the estimation of ecosystem carbon cycling rates and to distinguish 'fast' and 'slow' C pools, i.e. plant components with low or high carbon residence time (CRT). Comparative analyses of CRT in different ecosystem types along climate or elevation gradients may deepen our understanding of abiotic and biotic controls of ecosystem C cycling (Girardin et al. 2010; Malhi et al. 2017).

The moist tropical lowland forests of Africa are on average less species-rich than neotropical forests, but mean aboveground biomass is higher and average tree height greater (Hemp et al. 2017; Sullivan et al. 2017). In fact, biomass in tropical montane forests on Mt. Kilimanjaro is higher than in Andean montane forests (Ensslin et al. 2015). However, it is unknown if this higher biomass is also reflected in a higher productivity. Less is known about the carbon cycle of African tropical forests compared to their American and Asian counterparts. Apart from very few NPP measurements in lowland forest plots (e.g. Moore et al. 2018), only one productivity assessment has been done in an African tropical montane forest (Rwanda; Nyirambangutse et al. 2017). Mount Kilimanjaro, in northern Tanzania, with a forest belt covering an elevation gradient of approx. $2000 \mathrm{~m}$. from lower montane forest to the subalpine Erica forest, the highest forests of Africa (Hemp 2005), offers unique opportunities to study the variation in forest NPP and carbon allocation with temperature and moisture change, as soils are of similar origin (volcanic) and age. By determining all major components of NPP (aboveground wood increment, aboveground litter fall, fine root and coarse root production) in four characteristic forest types, total NPP and aboveground/belowground carbon allocation patterns were derived and related to temperature, rainfall and soil chemistry patterns on the mountain. We further calculated 
nitrogen use efficiency of productivity (NUE), carbon residence time, and the transfers of $\mathrm{C}$ and $\mathrm{N}$ with aboveground and belowground (root) litter fall to the soil for the different forest ecosystems in order to characterize putative factors influencing productivity along the elevation gradient.

The following hypotheses guided our research: (1) Total NPP declines and $\mathrm{C}$ allocation shifts to the fine root system as a consequence of increasing $\mathrm{N}$ limiting conditions with elevation; (2) nutrient use efficiency of productivity is higher at high elevations as a response to low soil $\mathrm{N}$ availability; (3) $\mathrm{C}$ and $\mathrm{N}$ fluxes from fine root mortality to the soil are more important than from leaf litter at high elevations as a result of plant species adaptation to the harsh conditions.

\section{Material and methods}

\section{Study site}

The study was conducted on the southern and southeastern slopes of Mount Kilimanjaro, northern Tanzania $\left(3^{\circ} 4^{\prime} 33^{\prime \prime} \mathrm{S}\right.$, $37^{\circ} 21^{\prime} 12^{\prime \prime} \mathrm{E}$ ), in the framework of the KiLi project, an interdisciplinary research project on biodiversity, biotic interactions and biogeochemical cycles in the main ecosystems of the mountain. From the foothills to the mountain top, a characteristic sequence of vegetation belts from savanna woodland through tropical montane forest to alpine heathland is found (Hemp 2006). The present study investigates four different types of tropical montane forest inside Kilimanjaro
National Park at elevations from 1800 to $3910 \mathrm{~m}$ a.s.l. Along three elevation transects, twelve study plots of 0.25 ha were demarcated in the four forest types, resulting in threefold replication at the plot level (Table 1). Detailed information about the forest ecosystems and their plant species composition is given in Hemp (2006). The lower montane forest (1800-2000 m a.s.1.) is characterized by Macaranga kilimandscharica, Agauria salicifolia and, to a lesser degree, Ocotea usambarensis. The middle montane forest (Ocotea forest, 2100-2800 m a.s.1.) is dominated by Ocotea usambarensis, Ilex mitis, Xymalos monospora and the tree fern Cyathea manniana, and contains a dense understory layer. The upper montane forest (Podocarpus forest, 2800-3000 m a.s.1.) hosts Podocarpus latifolius as the dominant tree species together with Hagenia abyssinica and Prunus africana. In the subalpine belt (i.e. the treeline ecotone sensu Körner (2012)) (3500-3900 m a.s.l), Erica bushlands with some remnants of Erica trimera forests are dominant, which form the tree line.

Mean annual temperature ranges from $15{ }^{\circ} \mathrm{C}$ in the lower montane forest to $4{ }^{\circ} \mathrm{C}$ in the highest Erica forest (Appelhans et al. 2015). Rainfall exhibits a bimodal seasonal distribution on Mt. Kilimanjaro with a long rainy season from March to May and a short rainy season around November (Hemp 2006). Mean annual precipitation decreases from $2200 \mathrm{~mm}$ in the lower montane forest (1800 $\mathrm{m}$ a.s.l.) to $1000 \mathrm{~mm}$ in the subalpine Erica forest belt (3900 m a.s.l.) (Hemp 2006).

The soils on the southern slopes of Mt. Kilimanjaro developed from the same volcanic deposits and are thus of
Table 1 Some physiographic and stand structural characteristics of the plots studied in the four forest types on Mt. Kilimanjaro. Given are means $\pm \operatorname{SE}(n=3)$

\begin{tabular}{lllll}
\hline & Lower montane forest & Ocotea forest & Podocarpus forest & Erica forest \\
\hline Elevation (m a.s.l.) & $1800-2040$ & $2120-2750$ & $2800-2970$ & $3500-3910$ \\
MAT $\left({ }^{\circ} \mathrm{C}\right)^{\mathrm{a}}$ & $14.7 \pm 0.3$ & $11.3 \pm 0.7$ & $9.3 \pm 0.3$ & $6.0 \pm 1.2$ \\
MAP $(\mathrm{mm})^{\mathrm{b}}$ & $2227 \pm 215$ & $1995 \pm 285$ & $1545 \pm 178$ & $1051 \pm 75$ \\
$\mathrm{C}: \mathrm{N}(\mathrm{topsoil})^{\mathrm{c}}$ & $15.9 \pm 0.7$ & $19.3 \pm 1.0$ & $18.6 \pm 1.3$ & $19.6 \pm 0.7$ \\
$\mathrm{pH}(\mathrm{KCl})($ topsoil) & $4.23-4.34$ & $3.49-4.23$ & $3.83-5.35$ & $4.45-4.54$ \\
WFPS $(\%)^{\mathrm{d}}$ & $21.6 \pm 8.4$ & $41.1 \pm 13.2$ & $36.1 \pm 11.5$ & $\mathrm{n} . \mathrm{d}$ \\
AGB $\left(\mathrm{Mg} \mathrm{ha}{ }^{-1}\right)^{\mathrm{e}}$ & $267.4 \pm 45.0$ & $328.8 \pm 83.6$ & $404.4 \pm 49.7$ & $32.5 \pm 7.2$ \\
Stem density $\left(\mathrm{n} \mathrm{ha}{ }^{-1}\right)^{\mathrm{e}}$ & $397 \pm 39$ & $311 \pm 36$ & $523 \pm 33$ & $2091 \pm 1196$ \\
Basal area $\left(\mathrm{m}^{2} \mathrm{ha}^{-1}\right)^{\mathrm{e}}$ & $47.1 \pm 9.8$ & $46.1 \pm 7.7$ & $55.7 \pm 5.1$ & $14.9 \pm 3.3$ \\
Mean tree height $(\mathrm{m})^{\mathrm{e}}$ & $15.6 \pm 0.9$ & $16.0 \pm 1.8$ & $15.5 \pm 1.3$ & $4.9 \pm 0.1$ \\
LAI $\left(\mathrm{m}^{2} \mathrm{~m}^{-2}\right)^{\mathrm{f}}$ & $6.25 \pm 0.03$ & $5.43 \pm 1.16$ & $5.09 \pm(0.54)$ & $2.15 \pm 0.22$ \\
Leaf C:N ratio $\left(\mathrm{mg} \mathrm{mg}^{-1}\right)$ & $19.2 \pm 0.6$ & $21.2 \pm 1.3$ & $29.4 \pm 3.2$ & $37.9 \pm 0.8$ \\
\hline
\end{tabular}

aMAT: mean annual temperature [Appelhans et al. (2015)]

bMAP: mean annual precipitation [Hemp (2006)]

${ }^{\mathrm{c}}$ Soil $\mathrm{C}: \mathrm{N}$ and $\mathrm{pH}$ range values $(0-10 \mathrm{~cm}$ of the topsoil) (Becker, unpublished data)

${ }^{\mathrm{d}}$ WPFS water-filled pore space $(0-5 \mathrm{~cm}$ topsoil) (weighted mean of measurements in the long and short rainy seasons, and the long and short dry seasons) [Gütlein et al. (2018)]

eAGB: aboveground biomass stand structural data of trees $>10 \mathrm{~cm}$ DBH [Hemp (unpublished data)], in case of Erica forest $\mathrm{DBH} \geq 5 \mathrm{~cm}$ (Schellenberger Costa, unpublished data)

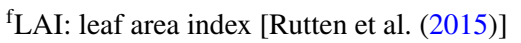


similar age (Dawson 1992). In the four forest types, andosols with folic, hystic or umbric properties are predominant, indicating high topsoil carbon contents (Zech 2006).

\section{Determination of NPP}

In all 12 plots, we measured aboveground wood increment, aboveground litterfall production, coarse root production and fine root production as the main components of net primary productivity over a 24-month interval (Aug 2014-Jul 2016) (Clark et al. 2001a). In the case of fine root production, the measuring period covered only one year (Aug 2015-Jul 2016). We assumed that a steady-state in the production of leaves, twigs, inflorescences and fruits, i.e. equality between the production of new organs and litterfall existed in the canopy (Aragão et al. 2009), as well as in the fine root system (Graefe et al. 2008).

\section{Aboveground productivity and coarse root production}

The production of aboveground biomass was derived from stem increment measurements with dendrometer tapes (UMS, München, Germany) mounted permanently on 40 stems per plot ( 480 stems in total). In the 0.25 ha-plots, the 40 stems were selected from the more abundant tree species and from different diameter classes to include the whole spectrum of stem diameters above $10 \mathrm{~cm} \mathrm{DBH}$. In case of the Erica forest, the DBH threshold was set to $\geq 5 \mathrm{~cm}$, as the 5-10 cm-class contributes significantly to total coarse wood biomass in this ecosystem. Dendrometer tapes were placed at $1.3 \mathrm{~m}$ height above ground. When buttresses or stem anomalies were present, we moved the dendrometers some centimeters higher or lower. Tape readings were conducted at monthly intervals from August 2014 to July 2016. Aboveground biomass production was calculated as the difference in biomass between the first and last reading, divided by interval length. To obtain aboveground biomass from DBH and tree height, we applied the pantropical allometric equation of Chave et al. (2014) (Eq. 1):

$$
A G B=0.0673\left(\rho D^{2} H\right)^{0.0976}
$$

in which AGB is the aboveground biomass estimate (in $\mathrm{kg}$ per tree), $\rho$ is the specific gravity of the wood (dry weight per fresh volume in $\mathrm{kg} \mathrm{m}^{-3}$ ), D the trunk diameter (DBH in $\mathrm{cm}$ ), and $\mathrm{H}$ tree height (in $\mathrm{m}$ ). AGB covers coarse wood biomass, and twig and leaf mass. This NPP component is termed hereafter NPP-aboveground wood. The procedures to measure specific wood gravity (wood density) and tree height in the plots are described in Ensslin et al. (2015) and Schellengerger Costa et al. (2017). When wood density data were not available from the plots (in 2 species and 16 stems), values were taken from the global wood density database
(Zanne et al. 2009). For stems that were not equipped with dendrometer tapes in the plots, we used increment rates averaged per species and per plot. For tree species that were not monitored, we used increment rates averaged over all measured species in the plot.

The production of coarse roots, i.e. roots with diameter $>5 \mathrm{~mm}$, was derived from measured aboveground biomass increment applying the equation given for tropical forests by Cairns et al. (1997) (Eq. 2).

$B G B=\exp (-1.0587+0.8836 \ln (A G B))$

with BGB being the belowground biomass and AGB the aboveground biomass, both in $\mathrm{Mg} \mathrm{ha}^{-1}$. The equation was primarily derived for root diameters $>5 \mathrm{~mm}$, but some of the included studies considered also fine roots. Since fine roots contribute with only a few percent to belowground biomass, we used the measured AGB difference between first and last reading for estimating the production of coarse root biomass (hereafter: NPP-coarse roots), the main component of belowground biomass.

To express NPP in terms of carbon (C), we used a C content of the biomass of $48.2 \%$ for all NPP components (Thomas and Martin 2012). Carbon residence time (CRT) of the NPP components was calculated by dividing the amount of $\mathrm{C}$ contained in the biomass by the $\mathrm{C}$ accumulated by the formation of new biomass (productivity) (Malhi et al. 2004). This was done for all NPP components except for aboveground litterfall, as canopy biomass was not measured.

\section{Aboveground litter production and its components}

Aboveground litterfall was measured with ten randomly placed litterfall traps (size: $1 \mathrm{~m} \times 1 \mathrm{~m}$ ) that were collected at monthly intervals from August 2014 to July 2016. PVC tubes were inserted at the corners of the traps and a nylon mesh of $1 \mathrm{~mm}$ mesh width placed $20 \mathrm{~cm}$ above ground between the four tubes. In the Ocotea forest, the net was located at $80 \mathrm{~cm}$ height to collect the litter above the understory vegetation layer. In the laboratory, the collected material was separated for leaves, twigs (diameter $<20 \mathrm{~mm}$ ) and other litter components (inflorescences, fruits, leaf fragments, unidentified material), oven-dried at $60{ }^{\circ} \mathrm{C}$ for one week, weighed and the mass expressed as litterfall per time interval and ha ${ }^{-1}$ (hereafter: NPP-aboveground litterfall). To obtain total aboveground NPP (NPP-aboveground), the NPP-aboveground litterfall was added to the NPP-aboveground wood.

The $\mathrm{C}$ and $\mathrm{N}$ content of all litter fractions was measured through gas chromatography with a $\mathrm{CN}$ elemental analyzer (Vario EL III, Hanau, Germany). We analyzed five samples per plot, each consisting of the mix of two samples from two sampling dates (May 2016 for the long wet season and July 2016 for the long dry season). For direct comparison with 
the fine root litter fraction, we calculated the leaf litter C:N ratio and the annual transfer of $\mathrm{C}$ and $\mathrm{N}$ with leaf litterfall to the soil, using plot-level means. The nitrogen use efficiency (NUE) of productivity was calculated in the different forest types after Vitousek (1982) by dividing annual aboveground litter mass by litter $\mathrm{N}$ content.

\section{Fine root production}

The available methods for measuring fine root productivity (NPP-fine roots) have reported divergent results in several studies (Hertel and Leuschner 2002; Hendricks et al. 2006; Moser et al. 2010). Therefore, it is advisable to combine at least two approaches to get an impression of the possible bias in the data (Clark et al. 2001a). In this study, we applied the sequential coring approach (Persson 1980; Majdi 1996) together with the ingrowth core method (Majdi et al. 1996). The first method has been widely used but is labor-intensive and may be problematic especially at sites with low root mass seasonality (Vogt et al. 1998; Hertel and Leuschner 2002). The second method has been found to underestimate fine root production, but it can be conducted with a relatively high number of replicates and may serve for comparing root production at different sites when root growth is fast, as is typically the case in tropical forests (Vogt et al. 1998). While the absolute productivity values obtained with the ingrowth core method seem to underestimate fine root production and may better be used to characterize the regeneration potential of the fine root system after disturbance, the figures from a large number of locations may nevertheless give an impression of relative differences in plot-level fine root productivity. On the other hand, some authors consider that minirhizotrons might be a quite reliable method to estimate fine root production, as the same roots are followed through time and a direct observation of death and growth is possible (Hendricks et al. 2006; Moser et al. 2010). However, it was not possible to include this approach on our study due to logistic issues.

Sequential coring approach Due to the high labor effort needed to collect and process the samples, the sequential coring approach was conducted in only one of the three elevation transects. On four occasions in the period August 2015-July 2016 (Aug 2015, Jan 2016, May 2016, Jul 2016), 15 soil cores $(3.5 \mathrm{~cm}$ in diameter) per plot and date were extracted down to $40 \mathrm{~cm}$ depth and stored at $5{ }^{\circ} \mathrm{C}$ until analysis. Coring on the subsequent date was conducted at a distance of $20 \mathrm{~cm}$ to the last one, moving to the corners of a square. In the laboratory, samples were washed through a sieve of $200 \mu \mathrm{m}$ mesh size and root fragments $>10 \mathrm{~mm}$ in length and $\leq 2 \mathrm{~mm}$ in diameter were picked out. Living and dead fine roots were distinguished under a stereomicroscope based on the degree of root elasticity, the cohesion of cortex, periderm and stele, and the turgidity of the cortex (Leuschner et al. 2001b). Fine roots from woody plants were selected by means of root morphology and branching patterns and the lack of visible suberinization. Only these roots were considered for further analysis. Root samples were dried at $70{ }^{\circ} \mathrm{C}$ for $48 \mathrm{~h}$ and weighed. Additionally, we applied the protocol proposed by Van Praag et al. (1988) and modified by Hertel and Leuschner (2002) to cover necromass fragments $<10 \mathrm{~mm}$ in length, which represent a large part of the necromass. Six samples per plot were selected, the larger root fragments ( $>10 \mathrm{~mm}$ ) extracted by hand, and the remaining of the sample spread homogenously on a filter paper $\left(730 \mathrm{~cm}^{2}\right)$ subdivided into 36 squares. In six randomly chosen squares all root fragments (mostly necromass) were extracted under the stereomicroscope and the mass determined by drying and weighing. This small necromass fraction was multiplied by six to extrapolate to the entire sample and added to the necromass fraction $>10 \mathrm{~mm}$ in length to obtain an estimate of total fine root necromass. We then extrapolated the mass of the small-root fraction to the fine root necromass of the remaining samples that were not included in this more detailed analysis, using linear regression equations between the masses of the small-root fragments and the larger dead fine root fraction. A mean ratio of small to large root fractions was used in cases when a regression equation could not be applied.

Fine root production was calculated with the "minimum-maximum" approach (Edwards and Harris 1977; McClaugherty et al. 1982) by subtracting the lowest mean fine root mass (biomass plus necromass; $n=15$ cores) from the highest mean in the 1-year measuring period, considering only significant differences between dates (Vogt et al. 1986). As this method does not take into account the simultaneous occurrence of fine root production and root mortality in the study period, underestimation of fine root production is possible (McClaugherty et al. 1982). For the other two transects, where the sequential coring method was not conducted, fine root production was estimated from the fine root biomass data of these transects (Sierra Cornejo et al. 2020) using a regression between root biomass and root production determined in the first transect. NPP-fine roots and NPP-coarse root were added to obtain NPP-belowground.

Ingrowth core study As a second independent method, an ingrowth core study was conducted in the 12 plots of the three transects. In September 2014 and February 2015 (dry season), ten ingrowth cores $(0-40 \mathrm{~cm}$ soil depth) were placed at random locations in each plot. After soil extraction with a $3.5 \mathrm{~cm}$-soil corer, all visible roots were removed in situ by hand and the original hole was refilled with the root-free soil. The original soil layer sequence and bulk density were restored as well as possible. The location of the core was precisely marked with three thin 
plastic sticks and a PVC tube on the surface of the same diameter of the core. No mesh was inserted in the soil to avoid growth barriers and further disturbance of the soil texture (Hertel et al. 2013; Kubisch et al. 2017). The locations were resampled after one year with the same corer. Samples were processed in the laboratory following the same protocol as used in the sequential coring approach but without the detailed study on the very small root particles. This step was not necessary because the retrieved cores contained mostly newly ingrown living fine roots. Fine root production was calculated as ingrown fine root mass (living and dead roots) in relation to the length of the period between the start of recolonization and harvest (Vogt et al. 1998). To determine the recolonization starting point in the four forest types, we installed four additional ingrowth cores per plot and resampled them at monthly intervals during the subsequent four months. According to this side study, fine roots started to grow into the cores in the lower montane forest two months after exposure, and in the Ocotea, Podocarpus and Erica forests after three months. These periods were subtracted from the 1-yearlong exposure period. Fine root production was expressed at an annual basis (in $\mathrm{Mg} \mathrm{ha}^{-1}$ year $^{-1}$ ). Due to logistic problems, we could not retrieve the ingrowth cores from four of the 12 plots (one plot per forest type). The missing production values were estimated from the mean ratio between fine root production and fine root biomass of a forest type.

Analagous to aboveground nutrient use efficiency, we calculated the nitrogen use efficiency of fine root production for the four forest types by dividing fine root production by the $\mathrm{N}$ content of fine root biomass. Fine root growth is set equal with fine root litter production, assuming a steady state between fine root production and mortality. This assumption is supported by the results of a study with minirhizotrons along an elevation gradient in the Ecuadorian Andes, where similar fine root growth and mortality rates were found (Graefe et al. 2008). In addition, it has been shown that a major trigger of fine root production is the response to fine root death by compensatory fine root growth (Leuschner et al. 2001a; Kubisch et al. 2017), fine root production depending on factors determining fine root lifespan (Eissenstat and Yanai 1997; Hertel and Leuschner 2002; Hertel et al. 2013). For this calculation, we used the fine root $\mathrm{N}$ content data of the fine root biomass survey by Sierra Cornejo et al. (2020).

Carbon and nitrogen fluxes to the soil with root mortality were estimated for the four forest types by multiplying the $\mathrm{C}$ and $\mathrm{N}$ content of the fine root biomass (Table $\mathrm{S} 1$, Sierra Cornejo et al. 2020) with the calculated fine root productivity in the plot, assuming equivalence of productivity and mortality.

\section{Statistical analysis}

All statistical analyses were conducted in R-3.4.0 (R Core Team 2017). The influence of forest type on total NPP was analyzed with an ANOVA using plot-level means of productivity data. Differences between forest types were detected with a Tukey HSD post-hoc test. Linear and non-linear regressions were calculated to relate (1) the different NPP components, the partitioning of carbon to different sinks, carbon residence time, and nutrient use efficiency (fine root or aboveground production) to elevation, and (2) the NPP components to climatic, edaphic and stand structural variables. Again, plot means were used in the regression analyses. The normality and homoscedasticity of the residuals were visually inspected. We used a significance level of $P<0.05$ throughout the study.

\section{Results}

\section{Elevational change in NPP}

Total NPP (NPP-aboveground plus NPP-belowground) decreased from the lower montane forest at 1800-2040 m a.s.l. $\left(17.8 \pm 1.4 \mathrm{Mg} \mathrm{ha}^{-1}\right.$ year $\left.^{-1}\right)$ to the subalpine Erica forest at 3500-3910 m $\left(5.8 \pm 0.4 \mathrm{Mg} \mathrm{ha}^{-1}\right.$ year $\left.^{-1}\right)$ (Table 2, Fig. 1). All NPP components except fine root productivity decreased continuously with elevation in size, with the steepest slope detected for NPP-aboveground litterfall (reduction to less than 10\%), a moderate slope in NPP-aboveground wood (reduction to about a quarter), and the slightest slope in NPP-coarse roots (Table 2, Fig. 2). The relative proportion of NPP-aboveground litterfall and NPP-aboveground wood changed only little between 1800 and $3200 \mathrm{~m}$ to drop sharply toward the subalpine Erica forest (Table 2). In contrast, fine root productivity calculated with the sequential coring approach remained relatively constant across the elevation transect with 3.6-4.7 $\mathrm{Mg} \mathrm{ha}^{-1}$ year $^{-1}$. In the lower montane, the Ocotea and the Podocarpus forest, 35-45\% of total NPP was contributed by aboveground litter production (mostly leaves, twigs $<20 \mathrm{~mm}$, and fruits), $25-30 \%$ by NPPfine roots, and $20-25 \%$ by NPP-aboveground wood. NPP partitioning was different in the Erica forest at the highest elevation, where about $70 \%$ of total NPP referred to fine root productivity, while aboveground NPP (NPP-wood and NPPlitter fall) contributed only c. 25\% (Fig. 1). Consequently, the proportion of NPP-fine roots to total NPP increased greatly at the transition from the Podocarpus to the Erica forest upslope, indicating a large belowground shift in carbohydrate allocation above $3000 \mathrm{~m}$ (Fig. 3). This shift was associated with a dramatic increase in the fine root:leaf litter ratio, as leaf litterfall was very small and fine root productivity relatively high in the Erica forest (Table 2). 
Table 2 Net primary productivity (NPP) and its components, carbon residence time (CRT) in different biomass components, and nitrogen (N) use efficiency of productivity in the four forest types

\begin{tabular}{|c|c|c|c|c|}
\hline & Lower montane forest & Ocotea forest & Podocarpus forest & Erica forest \\
\hline \multicolumn{5}{|l|}{ Production $\left(\mathrm{Mg} \mathrm{ha}^{-1}\right.$ year $\left.^{-1}\right)$} \\
\hline NPP total & $17.79 \pm 1.41(8.47)$ & $13.24 \pm 2.31(6.43)$ & $12.65 \pm 0.87(6.16)$ & $5.75 \pm 0.40(2.78)$ \\
\hline Aboveground production & $12.06 \pm 1.19(5.83)$ & $8.42 \pm 1.89(4.14)$ & $8.23 \pm 0.83(4.04)$ & $1.40 \pm 0.47(0.69)$ \\
\hline Canopy litterfall & $8.07 \pm 0.42(3.91)$ & $4.60 \pm 0.37(2.30)$ & $5.21 \pm 0.64(2.58)$ & $0.54 \pm 0.05(0.28)$ \\
\hline Leaves & $6.14 \pm 0.39(2.98)$ & $3.24 \pm 0.34(1.64)$ & $3.18 \pm 0.36(1.61)$ & $0.009 \pm 0.003(0.005)$ \\
\hline Branches & $0.95 \pm 0.19(0.45)$ & $0.45 \pm 0.09(0.22)$ & $0.59 \pm 0.12(0.29)$ & $0.32 \pm 0.05(0.16)$ \\
\hline Rest & $0.99 \pm 0.04(0.48)$ & $0.91 \pm 0.18(0.44)$ & $1.44 \pm 0.17(0.69)$ & $0.22 \pm 0.01(0.11)$ \\
\hline Wood & $3.99 \pm 0.82(1.92)$ & $3.82 \pm 1.63(1.84)$ & $3.02 \pm 0.29(1.45)$ & $0.86 \pm 0.42(0.42)$ \\
\hline Belowground production & $5.73 \pm 0.22(2.64)$ & $4.83 \pm 0.49(2.29)$ & $4.42 \pm 0.48(2.12)$ & $4.35 \pm 0.08(2.08)$ \\
\hline Fine roots Sequential coring & $4.65 \pm 0.02(2.12)$ & $3.80 \pm 0.34(1.79)$ & $3.57 \pm 0.54(1.71)$ & $4.07 \pm 0.20(1.95)$ \\
\hline Fine roots Ingrowth core & $1.14 \pm 0.14(0.51)$ & $1.12 \pm 0.31(0.54)$ & $1.42 \pm 0.11(0.66)$ & $0.47 \pm 0.06(0.22)$ \\
\hline Coarse roots & $1.08 \pm 0.20(0.52)$ & $1.03 \pm 0.39(0.50)$ & $0.85 \pm 0.07(0.41)$ & $0.27 \pm 0.12(0.13)$ \\
\hline$\%$ NPP Aboveground litterfall & $46 \pm 2$ & $36 \pm 4$ & $41 \pm 2$ & $9 \pm 1$ \\
\hline$\%$ NPP Aboveground wood & $22 \pm 3$ & $27 \pm 7$ & $24 \pm 2$ & $14 \pm 6$ \\
\hline$\%$ NPP Fine roots & $26 \pm 2$ & $30 \pm 5$ & $28 \pm 4$ & $72 \pm 8$ \\
\hline$\%$ NPP Coarse roots & $6 \pm 1$ & $7 \pm 2$ & $7 \pm 1$ & $5 \pm 2$ \\
\hline CRT Aboveground wood (year) & $68.8 \pm 5.1$ & $98.9 \pm 15.6$ & $133.8 \pm 9.4$ & $48.2 \pm 10.8$ \\
\hline CRT Coarse roots (year) & $45.5 \pm 2.9$ & $62.4 \pm 8.8$ & $81.6 \pm 4.9$ & $33.0 \pm 6.7$ \\
\hline CRT Fine roots (year) & $0.52 \pm 0.01$ & $0.36 \pm 0.04$ & $1.19 \pm 0.28$ & $0.64 \pm 0.23$ \\
\hline NUE (N) Canopy ( $\left.\mathrm{g} \mathrm{g}^{-1}\right)$ & $70.2 \pm 4.8$ & $72.1 \pm 1.7$ & $74.4 \pm 7.1$ & $111.9 \pm 9.7$ \\
\hline NUE $(\mathrm{N})$ Fine roots $\left(\mathrm{g} \mathrm{g}^{-1}\right)$ & $65.0 \pm 12.7$ & $58.9 \pm 2.2$ & $65.2 \pm 1.2$ & $145.1 \pm 6.6$ \\
\hline Fine root: leaf litter ratio $\left(\mathrm{g} \mathrm{g}^{-1}\right)$ & $0.76 \pm 0.04$ & $1.19 \pm 0.14$ & $1.15 \pm 0.19$ & $535.60 \pm 124.48$ \\
\hline
\end{tabular}

Given are means $\pm \mathrm{SE}(\mathrm{n}=3)$. Values in parentheses give carbon fluxes (in $\mathrm{Mg} \mathrm{C} \mathrm{ha}^{-1} \mathrm{year}^{-1}$ )

NPP-belowground NPP-fine roots (Sequential coring) plus NPP-coarse roots

(a)

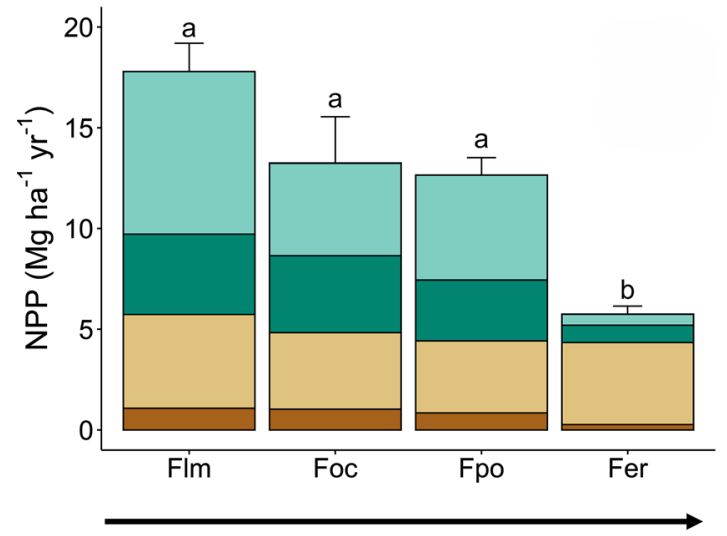

Elevation

Fig. 1 a Net primary productivity (NPP) of the four forest types by components, and $\mathbf{b}$ relative allocation of carbon to the different NPP components. All values are means $\pm \operatorname{SE}(n=3)$. Different lower case letters indicate significant differences between total NPP values of the

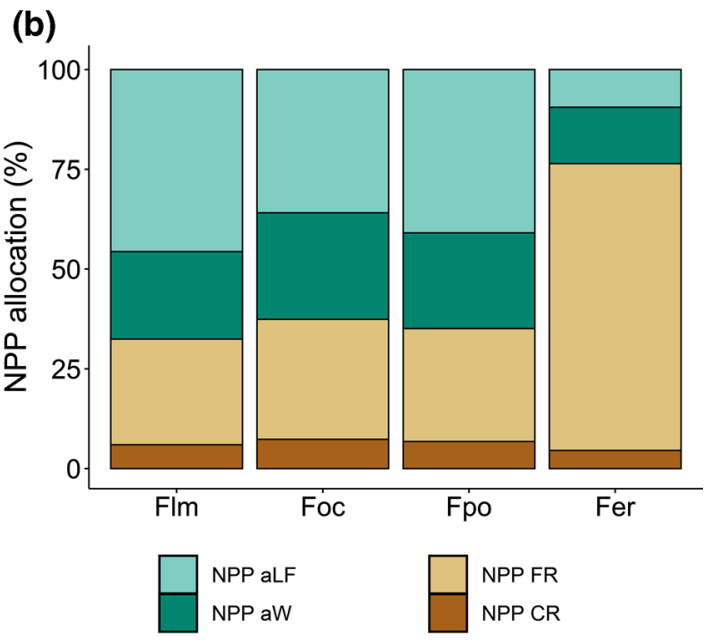

different forest types according to a Tukey HSD test $(P<0.05)$. Flm lower montane forest, Foc Ocotea forest, Fpo Podocarpus forest, $\mathrm{Fer}$ Erica forest, $a L F$ aboveground litterfall, $a W$ aboveground wood, $C R$ coarse roots, $F R$ fine roots 

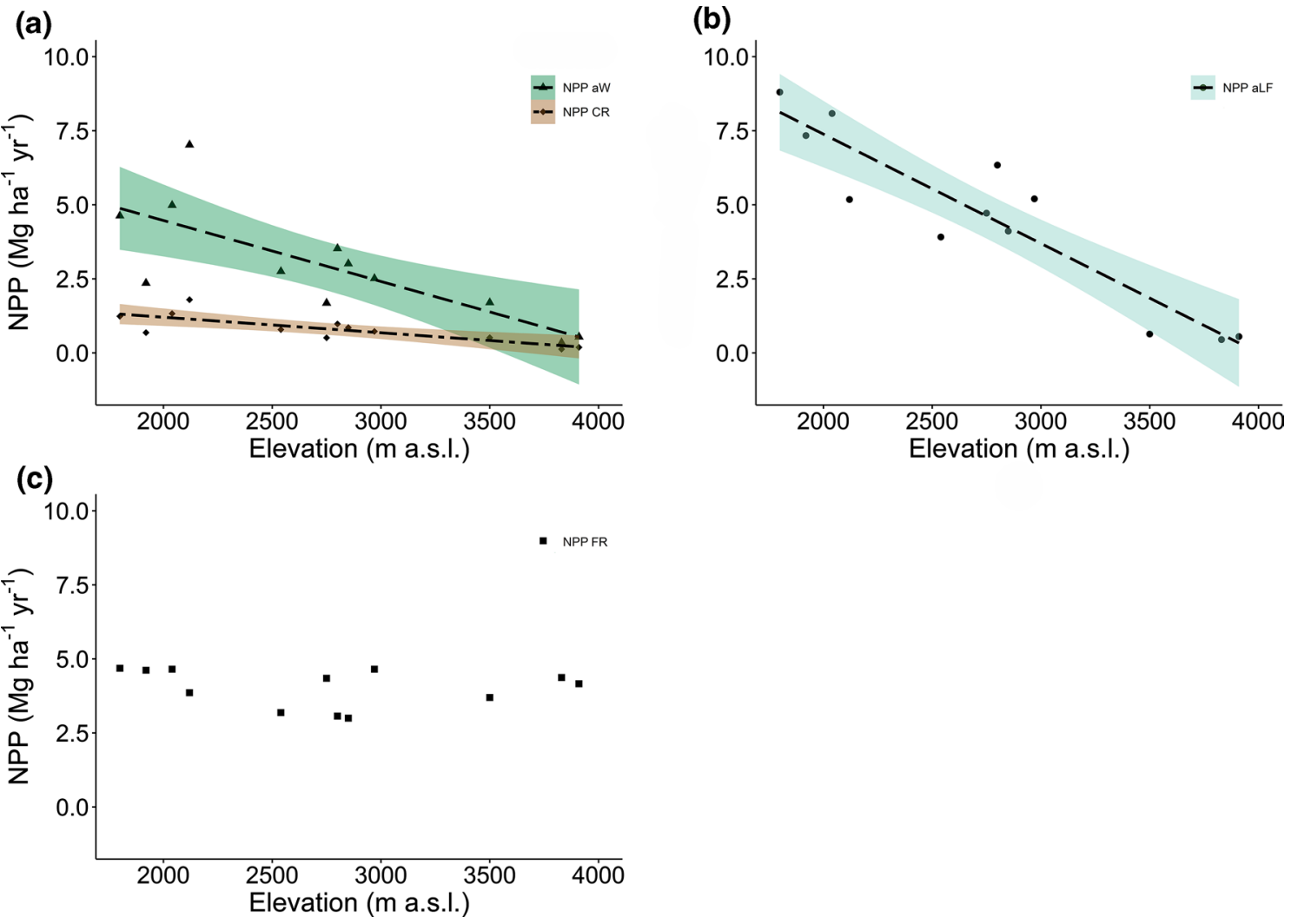

Fig. 2 Dependence on elevation of a aboveground wood productivity and coarse root productivity, $\mathbf{b}$ aboveground litter production, and c fine root productivity in the four forest types. Dashed lines indicate linear regressions, colored areas the $95 \%$ confidence interval

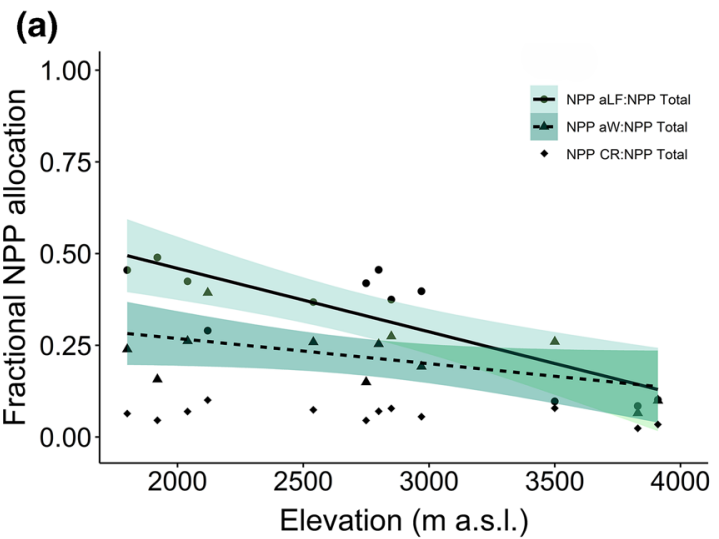

Fig. 3 Change with elevation in the proportion of a aboveground litter (leaves, fruits, twigs), aboveground wood productivity, and coarse root productivity, and b fine root productivity in total NPP in the four forest types. The different straight lines indicate linear regressions, the curved line a 2nd-order polynomial regression, the colored areas the $95 \%$ confidence
(NPPaW: $r^{2}=0.60 ; P<0.01 ;$ NPPCR: $r^{2}=0.62, P<0.01 ;$ NPPaLF: $r^{2}=0.85, P<0.001 ;$ NPPFR show no change with elevation; in all cases $n=12$ ). $a L F$ aboveground litter fall, $a W$ aboveground wood, $C R$ coarse roots, $F R$ fine roots

(b)

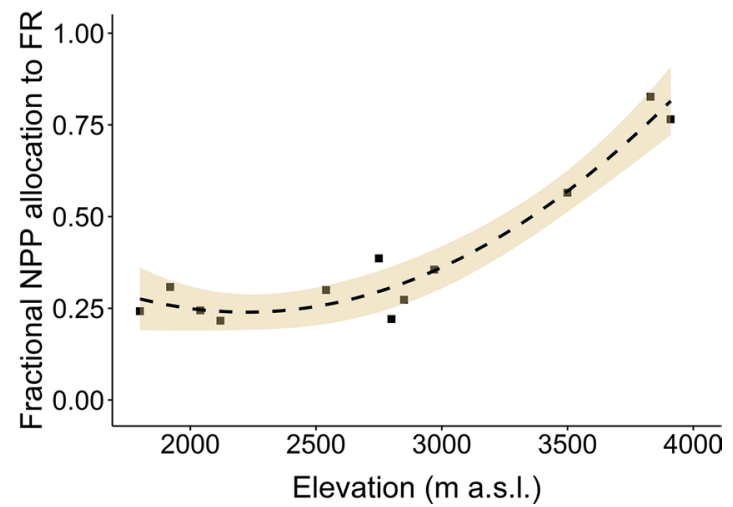

intervals. (NPPaLF: NPPtotal: $r^{2}=0.68, P<0.01$; NPPaW: NPPtotal showed no change with elevation: $r^{2}=0.31, P<0.1$; NPPCR: NPPtotal showed no change with elevation: $r^{2}=0.23$, $P=0.12$; NPPFR: NPPtotal: $r_{a d j}^{2}=0.93, P<0.001$; in all cases $n=12)$. $a L F$ aboveground litter fall, $a W$ aboveground wood, $C R$ coarse roots, $F R$ fine roots 
Fine root productivity estimated with the ingrowth core method gave three to four times (in case of the Erica forest even eight times) smaller annual productivity values than the corresponding sequential coring data (Table S2). As for the sequential coring data, no change with elevation was visible for the NPP-fine roots (IC) data (1.1.-1.4 $\mathrm{Mg} \mathrm{ha}^{-1}$ year $^{-1}$ ), but a reduction to the half occurred in the Erica forest (Table 2).

\section{Environmental drivers of NPP}

Total NPP and its components aboveground litter, aboveground wood and coarse root productivity showed a tight positive relation to mean annual temperature (and negative one to elevation; Table 3). The positive relation to MAP was also tight and in NPP-aboveground wood and NPP-coarse roots even closer than the relation to temperature. Total NPP and NPP-aboveground litterfall were negatively related to soil $\mathrm{C}: \mathrm{N}$ ratio, which was not the case in the other NPP components. In contrast, fine root productivity was related neither to elevation, climatic or soil factors nor to aboveground biomass or basal area (Table 3). Some of the biotic and abiotic factors were strongly correlated (Table S3).

\section{Carbon residence time and nitrogen use efficiency}

Carbon residence time (CRT) as the quotient of productivity and biomass in an NPP component ranged between 48 and 134 years in the aboveground biomass (wood) fraction, and between 33 and 82 years in the coarse root fraction (Table 2). CRT was highest in the conifer-dominated Podocarpus forest, and lowest in the Erica forest, resulting in a humpedshaped relation with elevation $\left(r^{2} a d j=0.80, P^{<} 0.001\right)$ (Fig. $\mathrm{S} 1)$. We determined CRT values (mean lifespans) for the fine root fraction of 0.36-1.19 years with a peak in the Podocarpus forest and a minimum in the Ocotea forest.

Table 3 Regression analysis relating the different productivity components to physiographic, edaphic and climatic, and stand structural variables across the four forest types on Mt. Kilimanjaro

\begin{tabular}{|c|c|c|c|c|c|c|c|c|c|c|c|c|c|c|}
\hline & \multicolumn{2}{|c|}{ Elevation } & \multicolumn{2}{|c|}{$\begin{array}{l}\text { Mean annual } \\
\text { temperature }\end{array}$} & \multicolumn{2}{|c|}{$\begin{array}{l}\text { Mean annual } \\
\text { precipitation }\end{array}$} & \multicolumn{2}{|c|}{ Soil C:N ratio } & \multicolumn{2}{|c|}{$\mathrm{pH}(\mathrm{KCl})$} & \multicolumn{2}{|c|}{$\begin{array}{l}\text { Aboveground } \\
\text { biomass }\end{array}$} & \multicolumn{2}{|c|}{ Basal area } \\
\hline & $r^{2}$ & $P$ & $r^{2}$ & $P$ & $r^{2}$ & $P$ & $r^{2}$ & $P$ & $r^{2}$ & $P$ & $r^{2} / r^{2} a d j$ & $P$ & $r^{2}$ & $P$ \\
\hline NPP total & -0.87 & $<0.001$ & 0.76 & $<0.001$ & 0.61 & $<0.01$ & -0.43 & $<0.05$ & -0.09 & n.s & 0.47 & $<0.05$ & 0.54 & $<0.01$ \\
\hline NPP aLF & -0.85 & $<0.001$ & 0.79 & $<0.001$ & 0.53 & $<0.01$ & -0.46 & $<0.05$ & -0.01 & $<0.1$ & 0.68 & $<0.01 *$ & 0.47 & $<0.05$ \\
\hline NPP aW & -0.60 & $<0.01$ & 0.46 & $<0.05$ & 0.55 & $<0.01$ & -0.21 & n.s & -0.21 & n.s & 0.32 & $<0.01$ & 0.60 & $<0.01$ \\
\hline NPP CR & -0.62 & $<0.01$ & 0.48 & $<0.05$ & 0.55 & $<0.01$ & -0.21 & n.s & -0.20 & n.s & 0.64 & $<0.01$ & 0.63 & $<0.01$ \\
\hline NPP FR & -0.04 & n.s & 0.05 & n.s & 0.01 & n.s & -0.09 & n.s & -0.01 & n.s & -0.18 & n.s & -0.11 & n.s \\
\hline
\end{tabular}

$\mathrm{NPP}$ in $\mathrm{Mg} \mathrm{ha}^{-1}$ year ${ }^{-1}$, elevation in m a.s.l., mean annual temperature in ${ }^{\circ} \mathrm{C}$, mean annual precipitation in mm, aboveground biomass in $\mathrm{Mg}$ $\mathrm{ha}^{-1}$ and basal area in $\mathrm{m}^{2} \mathrm{ha}^{-1}$. Significant relations are marked in bold $(P<0.05)$; nonlinear relations are indicated by $\left(^{*}\right)$ and the $\mathrm{r}^{2}{ }_{\text {adj }}$ is given. Negative relations are indicated by $(-)$

Given is the $r^{2}$ (adjusted $r^{2}$ in the case of nonlinear relations) and the $P$ value of the relationships

$a L F$ aboveground litter fall, $a W$ aboveground wood, $C R$ coarse roots, $F R$ fine roots

(a)

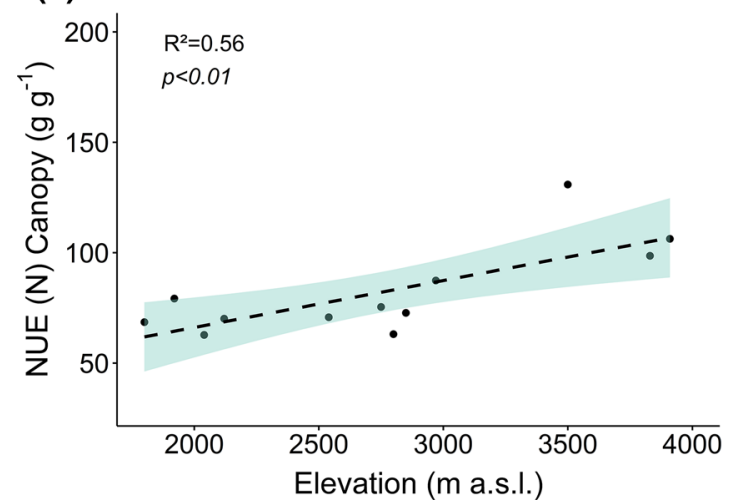

(b)

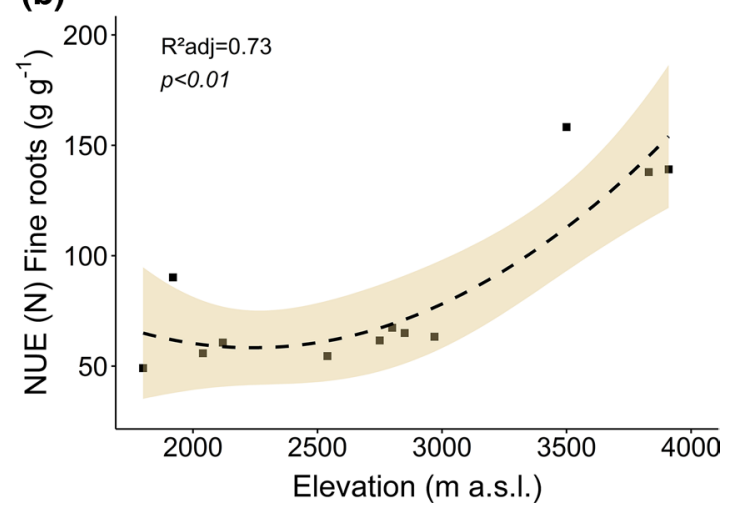

Fig. 4 Change with elevation in the nitrogen use efficiency of a canopy productivity and b fine root productivity in the four forest types. Dashed lines indicate linear regressions or 2 nd-order polynomial regressions $(n=12)$, colored areas the $95 \%$ confidence interval 
Nitrogen use efficiency of productivity (NUE) was relatively similar for aboveground litter and fine root productivity in a given forest type (Table 2). Both efficiencies remained on a similar level in all forest types except in the Erica forest, which showed 50 to $120 \%$ higher values (Fig. 4). NUE reached its highest value in the fine root productivity of the Erica forest $\left(145 \mathrm{~g} \mathrm{~g}^{-1}\right)$. The NUE values were negatively related to NPP across the four forest types (Table S4).

\section{Carbon and nitrogen transfers to the soil via leaf and root litter}

The leaf- and root-derived carbon and nitrogen fluxes were of similar size in the lower to upper montane forests, while the root litter flux greatly exceeded the leaf-born flux in the Erica forest $\left(195.1 \pm 9.7 \mathrm{~g} \mathrm{C} \mathrm{m}^{-2}\right.$ year $^{-1}$ and $2.8 \pm 0.3 \mathrm{~g} \mathrm{~N} \mathrm{~m}^{-2}$ year $^{-1}$ from fine roots vs. $0.5 \pm 0.2 \mathrm{~g} \mathrm{C}$ $\mathrm{m}^{-2}$ year $^{-1}$ and $0.01 \pm 0.005 \mathrm{~g} \mathrm{~N} \mathrm{~m}^{-2}$ year $^{-1}$ from leaves) (Table 4).

\section{Discussion}

\section{Decreasing net primary productivity with elevation and its causes}

Our replicated study of key productivity components in four mountain forest types along a 2000-m elevation gradient in tropical East Africa shows a continuous decline of total NPP with increasing elevation, that was associated with a marked belowground shift in carbon allocation toward the fine root system. With a decrease in mean annual temperature from 14.7 to $9.3{ }^{\circ} \mathrm{C}$, total NPP and its aboveground components NPP-aboveground litterfall and NPP-aboveground wood decreased by roughly $30 \%$ from the lower montane forest to the montane Podocarpus forest, contradicting the conclusions of Luyssaert et al. (2007) and Michaletz et al. (2014) who reported minor or no temperature effect on forest productivity in warm-temperate to tropical climates with $\operatorname{MAT}>10{ }^{\circ} \mathrm{C}$.

Total NPP values recorded in the four montane forest types on Mt. Kilimanjaro (2.8-8.5 $\mathrm{Mg} \mathrm{C} \mathrm{ha}^{-1}$ year $^{-1}$ ) were in the lower range of data from pantropical surveys of forest productivity (3.1-21.7 $\mathrm{Mg} \mathrm{C} \mathrm{ha}^{-1} \mathrm{year}^{-1}$ ) (e.g. Clark et al. 2001b; Kitayama and Aiba 2002; Aragão et al. 2009), but similar to figures from tropical montane forests in Rwanda $\left(9.2 \pm 2.1 \mathrm{Mg} \mathrm{C} \mathrm{ha}^{-1}\right.$ year $^{-1}$ ) (Nyirambangutse et al. 2017) and the Ecuadorian and Peruvian Andes (3.9-6.4 and 4.1-7.1 $\mathrm{Mg} \mathrm{C} \mathrm{ha}^{-1}$ year $^{-1}$, respectively; Moser et al. 2011; Girardin et al. 2010). The subalpine Erica forest at the tree line $\left(2.8 \mathrm{Mg} \mathrm{C}^{-1}\right.$ year $\left.^{-1}\right)$ had a $30 \%$ lower NPP than the corresponding upper montane forest at high elevations in the Ecuadorian Andes (3060 m a.s.1.) (4.1 Mg C $\mathrm{ha}^{-1}$ year $^{-1}$ ) (Moser et al. 2011) and almost $65 \%$ lower NPP than the tree line forest in the Peruvian Andes (3500 m a.s.1.) (7.9 $\mathrm{Mg} \mathrm{C} \mathrm{ha}^{-1}$ year $^{-1}$ ) (Malhi et al. 2017). Several factors may have contributed to this difference, among them the local species composition and related differences in stand structure, but also the regional climatic and edaphic conditions. The Ecuadorian upper montane forest has a larger stem density, basal area and mean tree height than the Erica forest in East Africa. The total NPP estimates in the Peruvian forest include measurements of small tree $(2-10 \mathrm{~cm}$ $\mathrm{DBH}$ ) productivity, leaf herbivory and carbohydrate transfer to the mycorrhiza (Malhi et al. 2017), which have not been quantified in our study. However, even when we increase our NPP value by $20 \%$ to account for these NPP components, the Peruvian tree line forest is still more productive than its counterpart in eastern Africa. Both Andean upper montane forests grow under higher precipitation and temperature levels than the Erica forest on Mt. Kilimanjaro (Moser et al.

Table 4 Estimated annual transfers of carbon and nitrogen to the soil with leaf litter production and with fine root mortality (sequential coring approach) in the four forest types

\begin{tabular}{|c|c|c|c|c|c|c|c|c|}
\hline \multirow[t]{2}{*}{ Ecosystem } & \multicolumn{2}{|c|}{ C flux $\left(\mathrm{g} \mathrm{m}^{-2}\right.$ year $\left.^{-1}\right)$} & \multicolumn{2}{|c|}{$\mathrm{N}$ flux $\left(\mathrm{g} \mathrm{m}^{-2}\right.$ year $\left.^{-1}\right)$} & \multicolumn{2}{|l|}{$\mathrm{N}\left(\mathrm{mg} \mathrm{g}^{-1}\right)$} & \multicolumn{2}{|c|}{$\mathrm{C}: \mathrm{N}$ ratio $\left(\mathrm{mg} \mathrm{mg}^{-1}\right)$} \\
\hline & Fine root litter & Leaf litter & $\begin{array}{l}\text { Fine root } \\
\text { litter }\end{array}$ & Leaf litter & $\begin{array}{l}\text { Fine root } \\
\text { litter }\end{array}$ & Leaf litter & $\begin{array}{l}\text { Fine root } \\
\text { litter }\end{array}$ & Leaf litter \\
\hline $\begin{array}{l}\text { Lower montane } \\
\text { forest }\end{array}$ & $211.72 \pm 7.44 \mathrm{a}$ & $298.48 \pm 16.23 b$ & $7.67 \pm 1.32 \mathrm{a}$ & $8.53 \pm 0.97 \mathrm{a}$ & $16.47 \pm 2.78$ & a $13.87 \pm 1.21 \mathrm{a}$ & $29.22 \pm 4.71 \mathrm{a}$ & $37.39 \pm 2.86 a$ \\
\hline Ocotea forest & $178.91 \pm 19.76 \mathrm{a}$ & $163.88 \pm 16.97 \mathrm{a}$ & $6.42 \pm 0.35 \mathrm{a}$ & $4.04 \pm 0.61 \mathrm{~b}$ & $17.02 \pm 0.66$ & a $12.37 \pm 0.62$ b & $27.71 \pm 1.54 \mathrm{a}$ & $45.26 \pm 1.89 \mathrm{~b}$ \\
\hline $\begin{array}{l}\text { Podocarpus } \\
\text { forest }\end{array}$ & $171.26 \pm 27.79 \mathrm{a}$ & $160.56 \pm 16.39 a$ & $5.51 \pm 0.92 \mathrm{a}$ & $3.84 \pm 0.93 \mathrm{a}$ & $15.35 \pm 0.27$ & a $11.84 \pm 1.68$ a & $31.16 \pm 0.40 \mathrm{a}$ & $46.25 \pm 6.51 \mathrm{a}$ \\
\hline Erica forest & $195.13 \pm 9.65 \mathrm{a}$ & $0.50 \pm 0.15 b$ & $2.83 \pm 0.25 \mathrm{a}$ & $0.011 \pm 0.005 b$ & $6.92 \pm 0.30 \mathrm{a}$ & $12.80 \pm 0.11^{*} \mathrm{~b}$ & $69.48 \pm 3.25 \mathrm{a}$ & $48.73 \pm 5.24 b$ \\
\hline
\end{tabular}

Also given are the $\mathrm{N}$ content and the $\mathrm{C}: \mathrm{N}$ ratio in the litter fractions. Assuming a steady state of fine root production and mortality, fine root production is equal to fine root litter production. Given are means $\pm \operatorname{SE}(n=3)$. Different lower case letters indicate significant differences between fine root and leaf litter fluxes in a given ecosystem according to ANOVA $(P<0.05)$ 
2011; Malhi et al. 2017), demonstrating the transition to a high-elevation climate with relatively low precipitation on top of the volcano $\left(1050 \mathrm{~mm}_{\text {year }}{ }^{-1}\right)$, whereas the uplift of moist air masses proceeds to higher elevations in the Andes.

Until recently, the change in forest productivity with elevation in tropical mountains was only studied with respect to aboveground NPP, while ignoring root productivity (Raich et al. 1997; Kitayama and Aiba 2002; Wang et al. 2003). Only the two studies from Peru and Ecuador by Girardin et al. (2010) and Moser et al. (2011) have investigated root production as well, allowing conclusions on elevational change in total NPP. The observed NPP trends differ between the three transects. While total NPP decreased more or less continuously from the lower montane to the upper montane forest in the Ecuadorian Andes (Moser et al. 2011; Leuschner et al. 2013), an abrupt productivity decline from the submontane $(1500 \mathrm{~m})$ to the cloud forest $(1700 \mathrm{~m})$ and nearly constant productivity higher upslope was found in the Peruvian Andes (Girardin et al. 2010; Malhi et al. 2017). In contrast, we found on Mt. Kilimanjaro a gradual NPP decline from the lower montane to the upper montane (Podocarpus) forest and an abrupt decrease toward the subalpine Erica forest. Carbon residence time in the wood increased from the more productive lower montane forest to the upper montane Podocarpus forest and sharply decreased to the Erica forest, revealing a hump-shaped curve along the slope. This pattern may partly be explained by the change from a forest with evergreen broadleaf trees to a conifer-dominated forest with Podocarpus latifolia and finally to an Erica trimera forest, which is exposed to more extreme minimum temperatures and of lower stature than the forests further downslope.

The data from Tanzania and Ecuador suggest that a major driver of the NPP decline is the reduction in leaf area index (LAI). In both transects, LAI decreased by more than $50 \%$ over a 2000-m elevation gradient from lower montane to upper montane elevation (Leuschner et al. 2007; Rutten et al. 2015). A decreasing photosynthetic capacity $\left(\mathrm{A}_{\text {sat }}\right)$ with elevation may also contribute to the productivity decline. According to a pan-tropical $\mathrm{A}_{\text {sat }}$ database, the light-saturated net photosynthesis of trees at ambient temperature decreases on average by $1.3 \mu \mathrm{mol} \mathrm{CO}_{2} \mathrm{~m}^{-2} \mathrm{~s}^{-1}$ per $1 \mathrm{~km}$ altitude increase in tropical mountains (Wittich et al. 2012). The decrease is typically linked to an altitudinal decrease in mass-related foliar N content (Moser et al. 2011; Schellenberger Costa et al. 2017). The results from the elevation transect in the Andes and eastern Africa indicate that both leaf area and photosynthetic capacity are influenced by the $\mathrm{N}$ supply along the mountain slope with the consequence that local and regional differences in soil fertility may cause somewhat different elevational trends in LAI, $\mathrm{A}_{\text {sat }}$ and total NPP.
Soil chemical and biological analyses in the Tanzanian and Ecuadorian transects indicate that $\mathrm{N}$ availability decreases with elevation in tropical mountains. On Mt. Kilimanjaro, both soil and leaf $\mathrm{C}: \mathrm{N}$ ratio increased with elevation toward the subalpine Erica forest, while fine root $\mathrm{N}$ content decreased, in conjunction with declining decomposition rate (Becker and Kuzyakov 2018). Moreover, we found a large increase in the $\mathrm{N}$ use efficiency of canopy and root productivity from the montane Podocarpus forest to the higher Erica forest on Mt. Kilimanjaro, linked to a pronounced shift in $\mathrm{C}$ allocation toward the root system. These findings explain the significant negative relation that exists between total NPP and soil C:N ratio in our four studied forest types. The elevational temperature decrease can influence $\mathrm{N}$ cycling through a negative impact on various processes, among them ammonification and nitrification, the diffusion of inorganic $\mathrm{N}$ compounds in the soil, the activity of mycorrhiza, and root $\mathrm{N}$ uptake (Chapin 1980; Pendall et al. 2004; Marschner 2012; Robertson and Groffman 2015). We assume that the temperature effect on $\mathrm{N}$ cycling and $\mathrm{N}$ supply and resulting reductions in leaf area (and possibly photosynthetic capacity) represent a major pathway through which elevation is acting on total $\mathrm{C}$ gain. In addition, tree growth was found to be stimulated by moderate nitrogen fertilization at the tree line ecotone in the Swiss Alps (Möhl et al. 2018), supporting our assumption of nutrient limitation of aboveground tree productivity at high elevations. The replacement of macrophyllous, broadleaved trees by southern hemispheric conifers at the upper montane zone and ericoid trees with more sclerophyllous leaves and their specialized ericoid mycorrhiza at the subalpine zone can also be interpreted as an indication of increasing nutrient limitation at higher elevations. There is a feedback between environmental conditions and functional composition. Of course, the species turnover with increasing elevation has an impact on forest productivity. It has been shown that the set of functional traits associated with a plant community is a strong driver of spatial variation in forest productivity (Fyllas et al. 2017). The plant species along the slope reflect in their traits the environmental change with elevation, which results from adaptation and acclimation to the local conditions (Chapin et al. 2011). We can see these adaptations along the slope of Mt. Kilimanjaro with the substitution of fast-growing species with high SLA as Macaranga kilimandscharica in the lower montane forest, where light is limiting, by slow-growing species as Podocarpus latifolius with lower SLA and nodules with mycorrhiza in the upper montane forest, with stronger $\mathrm{N}$ limiting conditions. Additionally, at the tree line, the sclerophyllous leaves and ericoid mycorrhiza, lower height and biomass of the monodominant Erica trimera are an adaptation to the extreme conditions (e.g. $\mathrm{N}$ limitation, strong wind, high irradiance, low temperature) at high elevations. Therefore, we focus our discussion on the 
change from light limiting conditions to $\mathrm{N}$ shortage along the slope, which result in lower LAI, lower photosynthetic capacity and thus, a decrease of total NPP. At the same time, the increasingly $\mathrm{N}$ limited conditions with elevation trigger a shift of the $\mathrm{C}$ allocation from aboveground to belowground organs in the woody plants.

Clearly, other environmental factors besides $\mathrm{N}$ supply must be responsible for the elevational NPP decrease as well, notably thermal limitation of meristem activity (Körner 2012). However, there is no physiological reason to assume that low temperatures should constrain aboveground meristematic activity more than belowground meristematic activity. Thus, a direct thermal effect on meristematic activity cannot explain the pronounced allocation shift toward root growth. Another factor possibly limiting forest productivity at higher elevations is reduced irradiance due to persistent cloud cover at montane elevation, as it was assumed for the Peruvian transect (Malhi et al. 2017). However, on Mt. Kilimanjaro, cloudiness was highest in the Ocotea forest belt (Hemp 2006), where total NPP was still comparatively high with $6.4 \mathrm{Mg} \mathrm{C}^{-1}$ year $^{-1}$, exceeding the NPP of the Erica forest higher up more than twofold. This makes it unlikely that enhanced light limitation in the cloud belt plays an important role in this transect.

The regression coefficients suggest that precipitation (MAP) is influencing NPP, but to a lesser degree than temperature and related phenomena such as nutrient supply. Our results are in line with an analysis of large NPP data sets that revealed an increase in the NPP of tropical forests with MAP until fairly high values ( $2500 \mathrm{~mm}$ ), followed by a decrease at even higher rainfall possibly due to reduced irradiance or reduced soil biological activity and $\mathrm{N}$ mineralization in wet soil (Schuur 2003; Del Grosso 2008). On Mt. Kilimanjaro MAP (not exceeding $2200 \mathrm{~mm}$ ) seems to promote forest NPP across the entire sequence of forest belts present on this mountain.

\section{Fine root productivity and elevational shifts in carbon allocation}

By including fine root production, our study is among the few that allows estimating the total NPP of tropical forest along elevation gradients and analyzing shifts in carbon allocation. These productivity data have to be interpreted with caution, however. The sequential coring and ingrowth core methods yielded largely different results, as has been found in other studies (Vogt et al. 1998; Hertel and Leuschner 2002; Moser et al. 2010). Both approaches have their shortcomings. The sequential coring technique with the minimum-maximum calculation approach is believed to underestimate fine root productivity when the seasonal variation in total fine root mass (live and dead) is larger than the difference between highest and lowest fine root mass count, and fine root decomposition is rapid (Vogt et al. 1998). The ingrowth core approach investigates root growth under more artificial conditions and starts from an injured root system. The growth rates estimated by this method may give an impression of the root system's regeneration potential rather than reflecting root productivity under natural conditions. As in the study of Moser et al. (2010), our ingrowth core productivity values were several times smaller than those obtained from sequential coring, especially at high elevations. Based on the ingrowth core data, we calculated fine root productivities in the range of $0.2-0.7 \mathrm{MgC} \mathrm{ha}^{-1}$ year $^{-1}$ and a mean carbon residence time between 1.4 and 5.0 years for the fine root fraction in the four forest types (Table S2). This is higher than fine root longevities derived from minirhizotron observation in tropical montane forests in the Ecuadorian Andes (0.70-0.95 years; Graefe et al. 2008) and also exceeds the average fine root longevity of 1.32 years found by Gill and Jackson (2000) for tropical forests in a meta-analysis (mostly sequential coring studies). According to our sequential coring data, average fine root longevity was $0.4-1.2$ years, which matches these figures better. We thus suggest that the sequential coring data may give a more realistic picture of fine root dynamics than the ingrowth core results, which have greater value for site comparison.

Three main conclusions may be drawn from our fine root productivity (sequential coring) data: (1) Fine roots are the most dynamic component in the studied tropical mountain forests, exceeding even the leaf fraction. (2) With 26 to $72 \%$ of total NPP, fine root productivity consumes more carbon than wood production. (3) In contrast to the other productivity components, fine root growth seems to be controlled mostly by intrinsic factors (probably sink strength and carbohydrate availability), as significant relations to climatic, edaphic and stand structural parameters were lacking. With the resource balance hypothesis (Bloom et al. 1985), the pronounced shift in carbon allocation from leaf growth (NPP-aboveground litterfall) to fine root growth from the upper montane Podocarpus to the subalpine Erica forest is interpreted as a change from predominant light limitation to nutrient (or water) limitation of growth. In our study, decreasing $\mathrm{N}$ supply with elevation is a plausible explanation, but a deficiency in other elements such as phosphorus $(\mathrm{P})$ or potassium is possible at tropical high-elevation sites (Graefe et al. 2010). Yet, leaf mass N:P ratios suggest primarily $\mathrm{N}$ limitation of growth on Mt. Kilimanjaro (Townsend et al. 2007). A belowground shift of $\mathrm{C}$ allocation has been concluded from studies on productivity or biomass changes along elevation transects in other tropical mountains (Leuschner et al. 2007, 2013; Girardin et al. 2010; Moser et al. 2011) and temperate mountains (Hertel and Schöling 2011; Mao et al. 2015) as well. Fine root studies at the alpine and arctic tree line also indicate that the $\mathrm{C}$ allocation preference of trees shifts belowground in cold environments 
(Ruess et al. 2003; Kubisch et al. 2017). As these studies were conducted mostly in humid climates, it is unlikely that water limitation is a possible driver of the allocation shift. Even though Mt. Kilimanjaro receives relatively low precipitation on its top, the amount in the Erica forest belt $(1050 \mathrm{~mm})$ seems to be high enough to exclude a main role of water shortage.

Thus, we assume that high-elevation forests in tropical mountains are not only limited by low temperatures that restrict meristem activity, but their growth seems to be constrained by nutrient (in particular N) shortage as well. Whether reductions in $\mathrm{N}$ supply, $\mathrm{N}$ diffusion in the soil, or impaired $\mathrm{N}$ uptake and relocation in the plant are primarily limiting, has to be addressed in physiological and soil chemical studies that should include soil warming experiments.

Fine roots are not only large sinks for photosynthates but also important sources of organic $\mathrm{C}$ and $\mathrm{N}$ which is transferred to the soil upon root death and via root exudation and transfer to the mycorrhiza (Rasse et al. 2005; Godbold et al. 2006). Our fine root productivity data suggest that the $\mathrm{C}$ and $\mathrm{N}$ flux to the soil with root litter is roughly of similar importance as the leaf litter flux in the lower montane and Ocotea forest, while it represents an important $\mathrm{C}$ and $\mathrm{N}$ source supplied by woody plants in the Erica forest. Comparable results have been obtained from Ecuadorian forests at high elevations (Röderstein et al. 2005). This highlights the need to include fine root dynamics in biogeochemical studies in forests of the tropics and elsewhere (Litton et al. 2007).

\section{Conclusions}

To our knowledge, this is the first study on forest productivity and its main above- and belowground components along an elevation transect on a paleotropical mountain. In accordance with earlier studies in neotropical elevation transects, we found a more or less continuous decrease of total NPP with elevation, confirming a pronounced temperature influence on forest productivity also in the temperature interval between 10 and $15^{\circ} \mathrm{C}$. Comparison with other tropical and non-tropical elevation transect studies reveals that the pronounced belowground shift in carbon allocation with elevation is a characteristic feature of mountain forests worldwide, suggesting increasing growth impairment through $\mathrm{N}$ (nutrient) limitation toward higher elevations, which seems to act independently from direct low-temperature effects on meristem activity. Inherent bias in the fine root productivity data warrants caution in the interpretation of the calculated fine root production data. Nevertheless, from the remarkable constancy of root productivity along the slope and the fairly good agreement with earlier neotropical fine root studies, we assume that the observed patterns are mostly valid. Future direct observational studies with mini-rhizotrons could provide a welcome independent estimate of fine root productivity. We conclude that initiatives to measure all major components of forest productivity along elevation gradients can generate valuable additional insights into the climate dependence of carbon cycling in woodlands.

Supplementary Information The online version contains supplementary material available at https://doi.org/10.1007/s00442-021-04860-8.

Acknowledgements We thank the Tanzanian Commission for Science and Technology (COSTECH), the Tanzania Wildlife Research Institute (TAWIRI) and the Mount Kilimanjaro National Park (KINAPA) for granting research and access permits. We are very grateful to our Tanzanian research assistants Jumanne Mwinyi, Ayubu Mtaturu, Upendo Nkya and Margreth Nkya as well as the laboratory staff in the Plant Ecology Department of Göttingen University. We are very thankful to the German Research Foundation (DFG) for funding through the Research-Unit 1246 (KiLi) and to the University of Göttingen and Projekt DEAL for enabling Open Access.

Author contribution statement DH developed the study design, NSC conducted the fieldwork, data processing and analysis, JNB, DSC and AH contributed with soil and stand structure data. AH selected and established the research plots. NSC, CL and DH interpreted the data and the paper writing was done by CL, NSC and DH with contributions of all authors.

Funding Open Access funding enabled and organized by Projekt DEAL. This study was funded by the German Research Foundation (DFG) within the Research-Unit 1246 (KiLi) which is gratefully acknowledged.

Data availability The datasets analyzed during the current study are available from the corresponding author on reasonable request.

\section{Compliance with ethical standards}

Conflicts of interest We declare no conflicts of interest.

Open Access This article is licensed under a Creative Commons Attribution 4.0 International License, which permits use, sharing, adaptation, distribution and reproduction in any medium or format, as long as you give appropriate credit to the original author(s) and the source, provide a link to the Creative Commons licence, and indicate if changes were made. The images or other third party material in this article are included in the article's Creative Commons licence, unless indicated otherwise in a credit line to the material. If material is not included in the article's Creative Commons licence and your intended use is not permitted by statutory regulation or exceeds the permitted use, you will need to obtain permission directly from the copyright holder. To view a copy of this licence, visit http://creativecommons.org/licenses/by/4.0/.

\section{References}

Appelhans T, Mwangomo E, Otte I et al (2015) Eco-meteorological characteristics of the southern slopes of Kilimanjaro, Tanzania. Int J Climatol 36:3245-3258. https://doi.org/10.1002/joc.4552

Aragão LEOC, Malhi Y, Metcalfe DB et al (2009) Above- and belowground net primary productivity across ten Amazonian forests 
on contrasting soils. Biogeosciences 6:2759-2778. https://doi. org/10.5194/bg-6-2759-2009

Becker JN, Kuzyakov Y (2018) Teatime on Mount Kilimanjaro: assessing climate and land-use effects on litter decomposition and stabilization using the Tea Bag Index. L Degrad Dev. https://doi. org/10.1002/ldr.2982

Bloom AJ, Chapin FS, Mooney HA (1985) Resource limitation in plants - an economic analogy. Annu Rev Ecol Syst 16:363-392

Cairns MA, Brown S, Helmer EH et al (1997) Root biomass allocation in the world 's upland forests. Oecologia 111(1):1-11. https://doi. org/10.1007/s004420050201

Cernusak LA, Winter K, Dalling JW et al (2013) Tropical forest responses to increasing atmospheric $\mathrm{CO} 2$ : current knowledge and opportunities for future research. Funct Plant Biol 40:531-551. https://doi.org/10.1071/FP12309

Chapin FS (1980) The mineral nutrition of wild plants. Annu Rev Ecol Evol Syst 11:233-260

Chapin FS, Matson PA, Vitousek PM (2011) Principles of terrestrial ecosystem ecology, 2nd edn. Springer, New York

Chave JR, Réjou-Méchain M, Búrquez A et al (2014) Improved allometric models to estimate the aboveground biomass of tropical trees. Glob Chang Biol 20:3177-3190. https://doi.org/10.1111/ gcb. 12629

Chu C, Bartlett M, Wang Y et al (2015) Does climate directly influence NPP globally? Glob Chang Biol 22:12-24. https://doi. org/10.1111/gcb.13079

Clark D, Brown S, Kicklighter DW et al (2001a) Measuring net primary production in forest concepts and field methods. Ecol Appl 11:356-370

Clark DA, Brown S, Kicklighter DW et al (2001b) Net primary production in tropical forests: an evaluation and synthesis of existeing field data. Ecol Appl 11:371-384. https://doi.org/10.2307/30608 95

Dawson JB (1992) Neogene tectonics and volcanicity in the North Tanzania sector of the Gregory Rift Valley: contrasts with the Kenya sector. Tectonophysics 204:81-92. https://doi.org/10.1016/00401951(92)90271-7

Del Grosso S (2008) Global potential net primary production predicted from vegetation class, precipitation, and temperature. Ecology 89:2117-2126. https://doi.org/10.2307/25661124

Edwards NT, Harris WF (1977) Carbon cycling in a mixed deciduous forest floor. Ecology 58:431-437. https://doi.org/10.2307/19356 18

Eissenstat DM, Yanai RD (1997) The ecology of root life span. Adv Ecol Res 27:1-62. https://doi.org/10.1016/S0065-2504(08)60005 $-7$

Eissenstat DM, Wells CE, Yanai RD, Whitbeck JL (2000) Building roots in a changing environment: implications for root longevity. New Phytol 147:33-42. https://doi.org/10.104 6/j.1469-8137.2000.00686.x

Ensslin A, Rutten G, Pommer U et al (2015) Effects of elevation and land use on the biomass of trees, shrubs and herbs at Mount Kilimanjaro. Ecosphere 6:3. https://doi.org/10.1890/ES14-00492.1

Fyllas NM, Bentley LP, Shenkin A et al (2017) Solar radiation and functional traits explain the decline of forest primary productivity along a tropical elevation gradient. Ecol Lett 20:730-740. https:// doi.org/10.1111/ele.12771

Gill RA, Jackson RB (2000) Global patterns of root turnover for terrestrial ecosystems. New Phytol 147:13-31

Girardin CAJ, Malhi Y, Aragão LEOC et al (2010) Net primary productivity allocation and cycling of carbon along a tropical forest elevational transect in the Peruvian Andes. Glob Chang Biol 16:3176-3192. https://doi.org/10.1111/j.1365-2486.2010.02235.x

Godbold DL, Hoosbeek MR, Lukac M et al (2006) Mycorrhizal hyphal turnover as a dominant process for carbon input into soil organic matter. Plant Soil 281:15-24. https://doi.org/10.1007/s1110 4-005-3701-6

Graefe S, Hertel D, Leuschner C (2008) Estimating fine root turnover in tropical forests along an elevational transect using minirhizotrons. Biotropica 40:536-542. https://doi.org/10.111 1/j.1744-7429.2008.00419.x

Graefe S, Hertel D, Leuschner C (2010) N, P and K limitation of fine root growth along an elevation transect in tropical mountain forests. Acta Oecologica 36:537-542. https://doi.org/10.1016/j.actao .2010.07.007

Gütlein A, Gerschlauer F, Kikoti I, Kiese R (2018) Impacts of climate and land use on $\mathrm{N}_{2} \mathrm{O}$ and $\mathrm{CH}_{4}$ fluxes from tropical ecosystems in the Mt. Kilimanjaro region, Tanzania. Glob Chang Biol 24:12391255. https://doi.org/10.1111/gcb.13944

Hemp A (2005) Climate change-driven forest fires marginalize the impact of ice cap wasting on Kilimanjaro. Glob Chang Biol 11:1013-1023. https://doi.org/10.1111/j.1365-2486.2005.00968.x

Hemp A (2006) Continuum or zonation? Altitudinal gradients in the forest vegetation of Mt. Kilimanjaro Plant Ecol 184:27-42. https ://doi.org/10.1007/s11258-005-9049-4

Hemp A, Zimmermann R, Remmele S et al (2017) Africa's highest mountain harbours Africa's tallest trees. Biodivers Conserv 26:103-113. https://doi.org/10.1007/s10531-016-1226-3

Hendricks JJ, Hendrick RL, Wilson CA et al (2006) Assessing the patterns and controls of fine root dynamics: An empirical test and methodological review. J Ecol 94:40-57. https://doi.org/10.111 1/j.1365-2745.2005.01067.x

Hertel D, Leuschner C (2002) A comparison of four different fine root production estimates with ecosystem carbon balance data in a Fagus-Quercus mixed forest. Plant Soil 239:237-251. https://doi. org/10.1023/A:1015030320845

Hertel D, Schöling D (2011) Norway spruce shows contrasting changes in below-versus above-ground carbon partitioning towards the Alpine treeline: evidence from a Central European case study. Arctic Antarct Alp Res 43:46-55. https://doi. org/10.1657/1938-4246-43.1.46

Hertel D, Strecker T, Müller-Haubold H, Leuschner C (2013) Fine root biomass and dynamics in beech forests across a precipitation gradient: is optimal resource partitioning theory applicable to water-limited mature trees? J Ecol 101:1183-1200. https://doi. org/10.1111/1365-2745.12124

Houghton RA (2005) Tropical deforestation as a source of greenhouse gas emissions. In: Moutinho P, Schwartzman S (eds) Tropical deforestation and climate change. Amazon Institute for Environmental Research. Environmental defense, Washington D.C, Belém, Pará, Brazil 13-21

Huxman TE, Smith MD, Fay PA et al (2004) Convergence across biomes to a common rain-use efficiency. Nature 429:651-654. https://doi.org/10.1038/nature02561

Kitayama K, Aiba SI (2002) Ecosystem structure and productivity of tropical rain forests along altitudinal gradients with contrasting soil phosphorus pools on Mount Kinabalu, Borneo. J Ecol 90:3751. https://doi.org/10.1046/j.0022-0477.2001.00634.x

Körner C (2012) Alpine treelines: functional ecology of the global high elevation tree limits. Springer, Basel

Kubisch P, Leuschner C, Coners H et al (2017) Fine root abundance and dynamics of Stone Pine (Pinus cembra) at the alpine treeline is not impaired by self-shading. Front Plant Sci 8:1-12. https:// doi.org/10.3389/fpls.2017.00602

Leuschner C, Backes K, Hertel D et al (2001a) Drought responses at leaf, stem and fine root levels of competitive Fagus sylvatica L. and Quercus petraea (Matt.) Liebl. trees in dry and wet years. For Ecol Manage 149:33-46. https://doi.org/10.1016/S0378 $-1127(00) 00543-0$ 
Leuschner C, Hertel D, Coners H, Büttner V (2001b) Root competition between beech and oak: a hypothesis. Oecologia 126(2):276-284. https://doi.org/10.1007/s004420000507

Leuschner C, Moser G, Bertsch C et al (2007) Large altitudinal increase in tree root/shoot ratio in tropical mountain forests of Ecuador. Basic Appl Ecol 8:219-230. https://doi.org/10.1016/j. baae.2006.02.004

Leuschner C, Zach A, Moser G, Homeier J, Graefe S, Hertel D, Wittich B, Soethe N, Iost S, Röderstein M, Horna V, Wolf K (2013) The carbon balance of tropical mountain forests along an altitudinal transect. In: Bendix J, Beck E, Bräuning A, Makeschin F, Mosandl R, Scheu S, Wilcke W (eds) Ecosystem services, biodiversity and environmental change in a tropical mountain ecosystem of South Ecuador. Springer, Berlin, pp 117-139

Lewis SL, Lopez-Gonzalez G, Sonké B et al (2009) Increasing carbon storage in intact African tropical forests. Nature 457:1003-1006. https://doi.org/10.1038/nature07771

Lichstein JW, Golaz N-Z, Malyshev S et al (2014) Confronting terrestrial biosphere models with forest inventory data. Ecol Appl 24:699-715. https://doi.org/10.1890/13-0600.1

Litton CM, Raich JW, Ryan MG (2007) Carbon allocation in forest ecosystems. Glob Chang Biol 13:2089-2109. https://doi.org/10 $.1111 / \mathrm{j} .1365-2486.2007 .01420 . x$

Lloyd J, Farquhar GD (2008) Effects of rising temperatures and CO2 on the physiology of tropical forest trees. Philos Trans R Soc B Biol Sci 363:1811-1817. https://doi.org/10.1098/rstb.2007.0032

Luyssaert S, Inglima I, Jung $\mathrm{M}$ et al (2007) $\mathrm{CO}_{2}$ balance of boreal, temperate, and tropical forests derived from a global database. Glob Chang Biol 13:2509-2537. https://doi.org/10.111 1/j.1365-2486.2007.01439.x

Majdi H (1996) Root sampling methods: applications and limitations of the minirhizotron technique. Plant Soil 185:255-258. https:// doi.org/10.1007/BF02257530

Malhi Y, Baker TR, Phillips OL et al (2004) The above-ground coarse wood productivity of 104 Neotropical forest plots. Glob Chang Biol 10:563-591 (1529-8817.2003.00778.x)

Malhi Y, Doughty C, Galbraith D (2011) The allocation of ecosystem net primary productivity in tropical forests. Philos Trans R Soc B Biol Sci 366:3225-3245. https://doi.org/10.1098/rstb.2011.0062

Malhi Y, Girardin CAJ, Goldsmith GR et al (2017) The variation of productivity and its allocation along a tropical elevation gradient: a whole carbon budget perspective. New Phytol 214:1019-1032. https://doi.org/10.1111/nph.14189

Mao Z, Wang Y, Jourdan C et al (2015) Characterizing above- and belowground carbon partitioning in forest trees along an altitudinal gradient using area-based indicators. Arct Antarct Alp Res 47:59-69. https://doi.org/10.1657/AAAR0014-014

Marschner P (2012) Mineral Nutrition of higher Plants, 3rd edn. Academic Press, London

McClaugherty CA, Aber JD, Melillo JM (1982) The role of fine roots in the organic matter and nitrogen budgets of two forested ecosystems. Ecology 63:1481-1490. https://doi.org/10.2307/1938874

Michaletz ST, Cheng D, Kerkhoff AJ, Enquist BJ (2014) Convergence of terrestrial plant production across global climate gradients. Nature 512:39-43. https://doi.org/10.1038/nature13470

Mitchard ETA (2018) The tropical forest carbon cycle and climate change. Nature 559:527-534. https://doi.org/10.1038/s4158 6-018-0300-2

Möhl P, Mörsdorf MA, Dawes MA et al (2018) Twelve years of low nutrient input stimulates growth of trees and dwarf shrubs in the treeline ecotone. J Ecol 107:768-780. https://doi. org/10.1111/1365-2745.13073

Moore S, Adu-Bredu S, Duah-Gyamfi A et al (2018) Forest biomass, productivity and carbon cycling along a rainfall gradient in West
Africa. Glob Chang Biol 24:e496-e510. https://doi.org/10.1111/ gcb. 13907

Moser G, Leuschner C, Röderstein M et al (2010) Biomass and productivity of fine and coarse roots in five tropical mountain forests stands along an altitudinal transect in southern Ecuador. Plant Ecol Divers 3:151-164. https://doi.org/10.1080/17550 874.2010.517788

Moser G, Leuschner C, Hertel D et al (2011) Elevation effects on the carbon budget of tropical mountain forests (S Ecuador): the role of the belowground compartment. Glob Chang Biol 17:2211-2226. https://doi.org/10.1111/j.1365-2486.2010.02367.x

Niang I, Ruppel OC, Abdrabo MA, Essel A, Lennard C, Padgham J, Urquhart P (2014) Africa. In: Barros VR, Field CB, Dokken DJ, et al (eds) Climate Change 2014: Impacts, Adaptation, and Vulnerability. Part B: Regional Aspects. Contribution of Working Group II to the Fifth Assessment Report of the Intergovernmental Panel on Climate Change. Cambridge University Press, Cambridge, United Kingdom and New York, NY, USA. 1199-1265

Nyirambangutse B, Zibera E, Uwizeye FK et al (2017) Carbon stocks and dynamics at different successional stages in an Afromontane tropical forest. Biogeosciences 14:1285-1303. https://doi. org/10.5194/bg-14-1285-2017

Pendall E, Bridgham S, Hanson PJ et al (2004) Below-ground process responses to elevated $\mathrm{CO}_{2}$ and temperature: a discussion of observations, measurement methods, and models. New Phytol 162:311-322. https://doi.org/10.1111/j.1469-8137.2004.01053.x

Persson H (1980) Fine-root production, mortality and decomposition in forest ecosystems. Vegetatio 41:101-109. https://doi.org/10.1007/ BF00121422

R Core Team (2017) R. A language and environment for statistical computing. $\mathrm{R}$ foundation for statistical computing, Vienna, Austria. https://www.R-project.org/

Raich JW, Russell AE, Vitousek PM (1997) Primary productivity and ecosystem development along an elevational gradient on Mauna Loa, Hawai'i. Ecology 78:707-721. https://doi. org/10.1890/0012-9658

Rasse DP, Rumpel C, Dignac MF (2005) Is soil carbon mostly root carbon? Mechanisms for a specific stabilisation. Plant Soil 269:341356. https://doi.org/10.1007/s11104-004-0907-y

Robertson GP, Groffman PM (2015) Nitrogen transformations. In: Eldor P (ed) Soil microbiology, ecology and biochemistry. Elsevier, Oxford, pp 421-446

Röderstein M, Hertel D, Leuschner C (2005) Above- and below-ground litter production in three tropical montane forests in southern Ecuador. J Trop Ecol 21:483-492. https://doi.org/10.1017/S0266 46740500249X

Ruess RW, Hendrick RL, Burton AJ et al (2003) Coupling fine root dynamics with ecosystem carbon cycling in black spruce forests of interior Alaska. Ecol Monogr 73:643-662. https://doi. org/10.1890/02-4032

Rutten G, Ensslin A, Hemp A, Fischer M (2015) Vertical and horizontal vegetation structure across natural and modified habitat types at Mount Kilimanjaro. PLoS ONE 10:1-15. https://doi. org/10.1371/journal.pone.0138822

Schellenberger Costa D, Classen A, Ferger S et al (2017) Relationships between abiotic environment, plant functional traits, and animal body size at Mount Kilimanjaro, Tanzania. PLoS ONE 12:1-15. https://doi.org/10.1371/journal.pone.0174157

Schuur EAG (2003) Productivity and global climate revisited: the sensitivity of tropical forest growth to precipitation. Ecology 84:1165-1170. https://doi.org/10.1890/0012-9658

Sierra Cornejo N, Hertel D, Becker JN et al (2020) Biomass, morphology, and dynamics of the fine root system across a 3000-m elevation gradient on Mt Kilimanjaro (2020). Front Plant Sci 11:13. https://doi.org/10.3389/fpls.2020.00013 
Sullivan MJP, Talbot J, Lewis SL et al (2017) Diversity and carbon storage across the tropical forest biome. Sci Rep 7:1-12. https:// doi.org/10.1038/srep39102

Thomas SC, Martin AR (2012) Carbon content of tree tissues: a synthesis. Forests 3:332-352. https://doi.org/10.3390/f3020332

Townsend AR, Cleveland CC, Asner GP, Bustamante MMC (2007) Controls over foliar N: P ratios in tropical rain forests. Ecology 88:107-118. https://doi.org/10.1890/0012-9658

Van Praag HJ, Sougnezremy S, Weissen F, Carletti G (1988) Root turnover in a beech and a spruce stand of the Belgian Ardennes. Plant Soil 105:87-103

Vitousek P (1982) Nutrient cycling and nutrient use efficiency. Am Nat 119:553-572. https://doi.org/10.1086/283931

Vogt KA, Grier CC, Gower ST et al (1986) Overestimation of net root production: a real or imaginary problem? Ecology 67:577-579. https://doi.org/10.2307/1938601

Vogt KA, Vogt DJ, Bloomfield J (1998) Analysis of some direct and indirect methods for estimating root biomass and production of forests at an ecosystem level. Plant Soil 200:71-89. https://doi. org/10.1023/a:1004313515294

Wang HQ, Hall CAS, Scatena FN et al (2003) Modelling the spatial and temporal variability in climate and primary productivity across the Luquillo Mountains, Puerto Rico. Forest Ecol Manag 179:69-94. https://doi.org/10.1016/S0378-1127(02)00489-9

Wittich B, Horna V, Homeier J, Leuschner C (2012) Altitudinal change in the photosynthetic capacity of tropical trees: a case study from ecuador and a pantropical literature analysis. Ecosystems 15:958 973. https://doi.org/10.1007/s10021-012-9556-9

Wood TE, Cavaleri MA, Reed SC (2012) Tropical forest carbon balance in a warmer world: a critical review spanning microbial- to ecosystem-scale processes. Biol Rev 87:912-927. https://doi. org/10.1111/j.1469-185X.2012.00232.X

Yuan W, Zheng Y, Piao S et al (2019) Increased atmospheric vapor pressure deficit reduces global vegetation growth. Sci Adv 5:8. https://doi.org/10.1126/sciadv.aax1396 (eaax 1396)

Zanne AE, Lopez-Gonzalez G, Coomes DA, et al (2009) Global wood density database. http://hdl.handle.net/10255/dryad.235

Zech M (2006) Evidence for Late Pleistocene climate changes from buried soils on the southern slopes of Mt. Kilimanjaro. Tanzania Palaeogeogr Palaeoclimatol Palaeoecol 242:303-312. https://doi. org/10.1016/j.palaeo.2006.06.008 